\author{
St u d a P hiloso phi c a \\ Wratis l a vi e n s i a \\ vol. XIV, fasc. 2 (2019) \\ DOI: $10.19195 / 1895-8001.14 .2 .3$
}

\author{
Ks. JÓZEF KOŻUCHOWSKI \\ ORCID: 0000-0001-6769-1473 \\ Wyższe Seminarium Duchowne w Elblągu \\ Wyższa Szkoła Społeczno-Ekonomiczna w Gdańsku
}

\title{
Problem eutanazji w ujęciu Roberta Spaemanna
}

\section{The problem of euthanasia as seen by Robert Spaemann}

Abstract: The main aim of the article is to present some aspects of euthanasia in the perspective of Robert Spaemann - one of the most significant contemporary German thinkers. First of all, the paradox of the right to euthanasia derived from one's own decision is pointed out. It is illustrated by the practice of legalising these acts in the Netherlands, Belgium and Luxembourg. On the one hand, such acts are to be motivated by our personal right to self-determination, but on the other, relevant decisions are taken by a doctor. Ultimately, the law protects the doctor, not the patient. Next, the nature of two main types of euthanasia is discussed and defined: active euthanasia and passive euthanasia. Also, an attempt is made to show the inevitable consequences of the right to kill oneself by answering the question whether the right to euthanasia breeds a sense of duty. Finally, a polemic between Robert Spaemann and Peter Singer is presented, which gives us an opportunity to see the three fundamental differences between these philosophers in their views on the problem of the so-called good death.

The author of the article emphasizes that the patient's living will, introduced in Germany in 2009 (Patientenverfügung), may indirectly imply consent to passive euthanasia, which is omitted in specialist literature. He then indicates the specificity of the philosophical argumentation of the eminent thinker against euthanasia. He also highlights two aspects of Spaemann's discussion with Singer: one concerns the 
downward spiral argument which undermines the legitimacy of euthanasia legalisation, and the other distinguishes two ways of abandoning the treatment if a person faces death.

Keywords: philosophy, person, euthanasia, self-determination, law

Krzysztof Sękowski

\section{Wprowadzenie}

Zmarły niedawno wybitny współczesny myśliciel niemiecki Robert Spaemann już przed prawie pięćdziesięciu laty w swoich filozoficznych dociekaniach podjął kwestię eutanazji, bodaj jeden z najważniejszych współczesnych problemów natury społecznej i etycznej na Starym Kontynencie. Swoje stanowisko w tej sprawie przedstawił w polemice ze zwolennikami tak zwanej dobrej śmierci, a jednocześnie reprezentantami dominujących współcześnie teorii etycznych utylitaryzmu i konsekwencjalizmu. W takim duchu rozważał tę problematykę także w ostatnich latach. W niniejszym artykule zostaną przedstawione wybrane aspekty Spaemannowskiego ujęcia problematyki eutanazji.

Autor najpierw ukaże moralny paradoks kryjący się w uprawnieniu do eutanazji, a następnie scharakteryzuje dwa jej rodzaje oraz odpowie na pytanie, czy prawo do eutanazji rodzi poczucie jej obowiązku. Wreszcie dla porównania przedstawi trzy fundamentalne różnice w spojrzeniu na eutanazję, jakie prezentują Robert Spaemann i Peter Singer, oraz wskaże, na czym polega oryginalność ujęcia niemieckiego myśliciela.

\section{Moralny paradoks uprawnienia do eutanazji na podstawie własnej decyzji}

Prawodawstwo dotyczące eutanazji chroni lekarza, a nie pacjenta ${ }^{1}$.

Zdaniem Spaemanna kluczowym punktem spornym w debacie na temat eutanazji jest pytanie, kto ostatecznie rozstrzyga o śmierci. Ze strony jej zwolenników przytaczany jest rzekomo silny argument z ludzkiej autonomii czy też prawa do samostanowienia. Ma to być etyczna i prawna legitymacja aktu eutanazyjnego ${ }^{2}$. Sam pacjent powinien bowiem mieć prawo rozstrzygania, kiedy i jak chciałby umrzeć i jeśli tego by sobie życzył, może zostać uśmiercony również na skutek ingerencji lekarskiej. Zwolennicy świadczenia eutanazji usiłują usprawiedliwiać i racjonalizować urzeczywistnienie pragnienia śmierci także innymi racjami, na przykład nieuleczalną chorobą. Według nich te konieczne dodatkowe kryteria są gwarancjami autonomii. Przeoczają jednak — podkreśla Spaemann — że w razie

\footnotetext{
${ }^{1}$ R. Spaemann, G. Hohendorf, F.S. Oduncu, Vom guten Sterben, Freiburg-Basel-Wien 2015, s. 134.

2 Ibidem, s. 130.
} 
ich zastosowania całkiem istotnie zostanie podważony ich najsilniejszy argument, jakim jest ta zasada ${ }^{3}$. W konsekwencji nie każdy człowiek może oczekiwać, że jego pragnienie ,pięknej śmierci”4 zostanie spełnione. Stanie się mu zadość tylko za sprawą przynależności do określonego kręgu ludzi i nie mocą samej autonomii, gdyż jako dodatkowe kryterium musi pojawić się nieuleczalna choroba i cierpienie nie do zniesienia. Dokładnie to bowiem jest wymagane i formułowane w istniejaccych prawach o eutanazji dla zagwarantowania wolnej od kary aktywnej pomocy w umieraniu i lekarskiego wsparcia w tym akcie, czyli pozbawianiu siebie życia (eutanazja czynna), w Holandii, Belgii i Luksemburgu. Żądanie takich dodatkowych kryteriów dotyka jednak wielu nierozwiązanych kwestii, które dotychczas w tej debacie zostały potraktowane raczej marginalnie.

Zwolennicy pomocy eutanazyjnej całkiem ignoruja obowiązek uzasadniania dodatkowych kryteriów związanych ze stwierdzeniem nieuleczalnej choroby, połączonej z cierpieniem nierokujacym nadziei ustania. Ostatecznie to lekarz, a zatem obca osoba trzecia, określa z zewnątrz na podstawie badań, że rzeczywiście występuje stan nieuleczalnej choroby połączony z cierpieniem nie do zniesienia (nie chodzi zatem o subiektywne odczucie i subiektywne pragnienie samego pacjenta).

Zatem na jakiej podstawie tylko pacjenci spełniający te kryteria maja prawo do ich uśmiercenia przy użyciu środków medycznych? Czyż poważnie traktowana zasada autonomii nie opiera się raczej na tym, że każdy z nas może określać kryteria oceny swego życia i cierpienia tak od strony moralnej, jak i prawnej — pyta słusznie Spaeman ${ }^{5}$. Konsekwentnie do tego każda prośba o zadanie śmierci wyrażona przez dorosłego, poczytalnego i poinformowanego o swoim stanie człowieka musiałaby być spełniona. Innymi słowy, dlaczego inne trudne sytuacje życiowe, jak na przykład utrata ukochanego człowieka lub zwykłe zniechęcenie życiem, nie upoważniają do tego, by zagwarantować wolną od kary aktywną pomoc przy umieraniu i samobójstwie?

Ograniczenie udzielania pomocy przy popełnianiu samobójstwa do określonych stanów cierpienia bezwzględnie zawęża zasadę samostanowienia, a nawet się jej sprzeciwia. Słusznie zatem, zdaniem niemieckiego myśliciela, zwolennicy takiej aktywnej pomocy (Sterbehilfe) sami doprowadzają swój najsilniejszy argument, mianowicie z autonomii, ad absurdum ${ }^{6}$.

Aby pragnienie śmierci i wykonanie czynności lekarskich, które prowadzą do eutanazji, stało się możliwe, jej zwolennicy takim dodatkowym kryteriom dają pierwszeństwo wobec zasady autonomii. W ten sposób usiłują ,racjonalizować” tego rodzaju pragnienie, czyli czynić je zrozumiałym dla tych, którzy mają udzielić pomocy eutanazyjnej. Za zrozumiałą natomiast rację często uważa się jedynie

\footnotetext{
${ }^{3}$ Ibidem.

${ }^{4}$ Takie znaczenie etymologiczne przypisuje się greckiemu słowu „,نं $\theta \alpha v \alpha \sigma i \alpha ”$. A. Hermann, Euthanasie, Historisches Wörterbuch der Philosophie, J. Ritter (hrsg.), Bd. 2, Stuttgart 1972, s. 828.

${ }^{5}$ R. Spaemann, G. Hohendorf, F.S. Oduncu, Vom guten Sterben, s. 131. Por. także R. Spaemann, Nie istnieje dobre zabijanie, [w:] idem, Granice. O etycznym wymiarze działania, tłum. J. Merecki, Warszawa 2006, s. 518.

${ }^{6}$ R. Spaemann, Nie istnieje dobre zabijanie, s. 518. Por. także R. Spaemann, G. Hohendorf, F.S. Oduncu, Vom guten Sterben, s. 131.
} 
nieuleczalną chorobę. Ocena jednak poszczególnych kryteriów, jak zauważa Spaemann, okazuje się trudna. Jedne z nich są subiektywne, a zatem związane ze stanem pacjentów (,cierpienie nie do zniesienia ”), drugie zaś rzekomo obiektywne, ustalone przez lekarza (,stan nierokujący nadziei”, „sytuacja bez wyjścia”), ale ani jedne, ani drugie nie są jasno określone i wyraźnie sprecyzowane ${ }^{7}$. Nie chodzi tu zatem o samą zasadę autonomii, lecz raczej o wykazanie „racjonalnego” charakteru pragnienia śmierci.

Można zatem sądzić, że powołanie się na prawo autonomii jest wprawdzie konieczne, ale nie ręczy uzyskania pomocy przy uśmierceniu lub samouśmierceniu. Jest to idea co najmniej podświadomie przyjmowana przez zwolenników eutanazji, albowiem w przeciwnym razie nie wprowadzaliby do dyskusji żadnych dodatkowych kryteriów. Jeśli jednak prawo do samostanowienia na gruncie zasady autonomii powinno być przyznawane i realizowane tylko pod warunkiem zastosowania dalszych dodatkowych kryteriów, wtedy występuje niepozwalający się rozwiązać moralny paradoks. Zasada autonomii albo obowiązuje per definitionem zawsze bez uciekania się do jakichkolwiek zewnętrznych pomocniczych kryteriów, albo w ogóle nie ma racji bytu.

Na podstawie danych empirycznych (skonkretyzowanych w liczbach) dotyczących praktyki eutanazji w Holandii i Belgii należy wątpić, czy faktycznie wszyscy pacjenci dobrowolnie i autonomicznie żądaja pomocy przy umieraniu. Wiele przykładów dowodzi czegoś przeciwnego, to jest niedobrowolnego żądania eutanazji. Wiemy dzisiaj, jak akcentuje Spaemann, że w większości przypadków pragnienie odebrania sobie życia nie jest wynikiem fizycznych dolegliwości i skrajnego bólu, lecz wyrazem opuszczenia (na skutek niedostatecznej opieki medycznej i braku wsparcia ze strony najbliższych) oraz lęku, by nie stać się dla rodziny obciążeniem, między innymi finansowym ${ }^{8}$. Ciężko chorzy oraz umierający zbyt boleśnie doświadczają tego, że mogliby stać się dla najbliższych ogromnym balastem, gdyby nie skorzystali z możliwości pozbawienia siebie życia, jaką oferuje przecież prawo - konstatuje Spaemann ${ }^{9}$.

Z pewnością niepowątpiewalny jest lekarski paternalizm dochodzący do głosu w formie krępowania i lekceważenia wolności pacjenta. W Holandii ujawnia się on w tym, że lekarze przychylają się do około zaledwie jednej trzeciej (trzy i pół tysiąca na dziesięć tysięcy) wyraźnie zadeklarowanych żądań eutanazji rocznie, a jeśliby chcieć respektować zasadę autonomii, wówczas powinny być zrealizowane wszelkie bez wyjątku żądania śmierci. Wtedy jednak musiałoby zostać uśmierconych medycznie około dziesięciu tysięcy osób rocznie.

Jednocześnie wiele setek ciężko chorych pacjentów, nawet bez wyraźnie wyartykułowanej prośby, że pragnie zakończyć swoje życie, jest tego życia pozbawiana przez lekarzy. Wymowna jest w takim wypadku najczęstsza argumentacja przedstawicieli świata medycznego, że ich zdaniem wszelkie formy terapii okazały się bezskuteczne, a krewni nie byli już w stanie znosić takiego stanu rzeczy. Wizja wy-

\footnotetext{
7 Ibidem.

${ }^{8}$ R. Spaemann, Nie istnieje dobre zabijanie, s. 521.

${ }^{9}$ R. Spaemann, Töten auf Verlangen?, „Psychologie heute” 25 [2] (1999), s. 48.
} 
idealizowanej „wolności do śmierci” (autonomii) staje się tutaj w coraz większym stopniu zarówno zagrożeniem życia, jak i przez to także pod pewnym względem pozbawieniem „wolności do życia” — konstatuje trafnie Spaemann ${ }^{10}$. Tym samym wizja ta przemienia się w postępujące ubezwłasnowolnienie pacjenta. Przy tego rodzaju legalizacji eutanazji coraz więcej ludzi godzi się z przymusem usprawiedliwiania. Są to zarówno ci, którzy pomimo psychicznego lub organicznego cierpienia i nieuleczalnej choroby nadal żyją, jak i osoby chcące zachować przy życiu umierajaccych krewnych. Unaoczniają to trzy wybrane, opisane poniżej sytuacje.

Pierwsza sytuacja. Oto pewna kobieta, która nie chciała dłużej troszczyć się o swego męża, postawiła go przed wyborem między eutanazją a pobytem w domu starców. Mężczyzna wybrał śmierć. Chociaż lekarz prowadzący był doskonale zorientowany w sytuacji w żaden sposób nie starał się przeszkodzić, żeby mężczyzna nie targnął się na swoje życie. O innym osobliwym przypadku opowiadał holenderski lekarz Ganning, wspominając starszego mężczyznę, którego śmierci rodzina oczekiwała niecierpliwie każdego dnia. Jego syn bowiem oznajmił lekarzowi, że zaplanował sobie urlop, z którego nie może zrezygnować, dlatego pogrzeb ojca powinien odbyć się jeszcze przed jego wyjazdem. Lekarz zaaplikował więc owemu pacjentowi sporą dawkę morfiny z wyraźnym zamiarem jego uśmiercenia. Gdy po chwili wrócił, aby stwierdzić zgon, ujrzał mężczyznę radośnie uśmiechniętego, siedzącego na swoim łóżku. Okazało się, że pacjent otrzymał wreszcie taką porcję morfiny, która pozwoliła złagodzić dręczący i nie do zniesienia ból. I ostatnia sytuacja. Pewien internista, który miał skierować do kliniki chorą na raka płuc kobietę z objawami niedotlenienia, musiał ją najpierw zapewnić, że nie grozi jej eutanazja, gdyż tej najbardziej się obawiała. Po zapewnieniu, że może być spokojna, skierował ją do szpitala i tam po trzydziestu sześciu godzinach jej oddech stał się normalny, a samopoczucie polepszyło się. Gdy jednak ów lekarz wrócił do siebie, kobietę poddał eutanazji jego kolega, swoją decyzję usprawiedliwiając tym, że potrzebowali łóżka dla innego pacjenta, a dla tej kobiety było rzeczą obojętną, czy umrze teraz, czy też czternaście dni później.

Jak podkreśla Spaemann, przeprowadzone badania dotyczące stosowania eutanazji w Holandii dowodzą, że praktycznie wszelkie wspomniane kryteria rzetelności z łatwością są pomijane ${ }^{11}$. Inaczej mówiąc, dobrowolność, samostanowienie i subiektywnie doznawane cierpienie odgrywają podrzędną rolę, ponieważ ciężko chory pacjent faktycznie zdany jest na lekarza i swoją rodzinę. Lekarz stosujący eutanazję za każdym razem może odstąpić od wymaganego obowiązku rzetelności, gdy tylko potrafi upozorować naturalną przyczynę zgonu. Prawodawstwo odnoszące się do eutanazji chroni zatem lekarza, a nie pacjenta. Z tego względu w Holandii coraz więcej ludzi z lęku przed niechcianym zabójstwem medycznym dołącza do swych dokumentów pewien rodzaj oświadczenia woli pacjenta (tzw. Credo Card) z napisem: „Lekarzu, nie zabijaj mnie”, ażeby zabezpieczyć się przed eutanazją. W sumie praktyka świadczenia pomocy w umieraniu tam, gdzie eutanazja została zalegalizowana, doprowadziła do moralnego paradoksu. Od początku niepewna

\footnotetext{
${ }^{10}$ R. Spaemann, G. Hohendorf, F.S. Oduncu, Vom guten Sterben, s. 132-133.

11 Ibidem, s. 139-140.
} 
pozycja pacjenta w zderzeniu z dominującą i paternalistycznie zorientowaną medycyną, która była kołem zamachowym ruchu na rzecz eutanazji, wciąż się osłabia. Z kolei od początku silna pozycja lekarza względnie przewaga medycyny, która stała się drugim kołem zamachowym ruchu promującego eutanazję, systematycznie się umacnia. W tym właśnie kryje się moralny paradoks ${ }^{12}$.

\section{Eutanazja czynna i bierna}

W swoich analizach o eutanazji Spaemann odwołuje się do znanych klasyfikacji tego problemu. Mówi więc o eutanazji dobrowolnej i niedobrowolnej, a także bezpośredniej. Zasadniczo jednak rozumie ją w duchu encykliki Evangelium vitae (EV). Jej przesłanie pozwala wyróżnić dwa podstawowe rodzaje eutanazji: czynną i bierną. Według tego dokumentu papieskiego ,przez eutanazję w ścisłym i właściwym sensie należy rozumieć czyn lub zaniedbanie, które ze swej natury lub w intencji działającego powoduje śmierć w celu usunięcia cierpienia" (EV 65) ${ }^{13}$. Z moralnego punktu widzenia eutanazja zarówno czynna, jak i bierna jest nie do usprawiedliwienia, gdyż jawi się jako działanie sprzeczne z obiektywną normą etyczną. Odpowiedzialność moralna lekarza jest identyczna w obydwu przypadkach takiego działania. Rozstrzyga o tym intencja spowodowania śmierci pacjenta.

Pod pojęciem eutanazji czynnej, jak podkreśla Spaemann, rozumie się bezbolesne uśmiercenie człowieka, aby natychmiast położyć kres jego cierpieniu. Lekarz wstrzykuje pacjentowi śmiertelną dawkę medykamentu i w ten sposób aktywnie powoduje jego śmierć. Jeżeli dzieje się to na wyraźne życzenie pacjenta, wtedy mówi się o śmierci na żądanie ${ }^{14}$. Tego rodzaju uśmiercenie traktuje się w Niemczech, podobnie jak w wielu innych krajach, jako czyn karalny. Precyzuje to paragraf 216 niemieckiego kodeksu karnego: „Ten kto dopuścił się zabójstwa jakiejś osoby na wyraźne i poważne jej życzenie, podlega karze pozbawienia wolności od sześciu miesięcy do pięciu lat" ${ }^{15}$. Znajduje tu więc potwierdzenie, zdaniem Spaemanna, teza Hegla: „Dziełem absolutnej wolności jest śmierć". Z jednej strony nikomu nie wolno uśmiercać drugiego jako podmiotu wolności, ale z drugiej nikt też nie ma prawa zwracać się do kogoś z taką prośbą, by usłyszeć: „Ty już nie powinieneś żyć”16. Dla usprawiedliwienia aktywnej pomocy w umieraniu jej zwolennicy przytaczają dwie zasady etyczno-medyczne. Według pierwszej z nich respekt dla zasady samostanowienia pacjenta, który pragnie śmierci, ażeby uwolnić się od cierpienia, nakazuje wyjść naprzeciw takiemu życzeniu. Natomiast wedle zasady drugiej spowodowanie śmierci nie wyrządza krzywdy pacjentowi i pozostaje w zgodzie z regułą czynienia dobra. Istnieją jednak przypadki świadczące o uśmiercaniu ludzi nie w wyniku wyartykułowanego przez nich pragnienia śmierci. Chodzi o tych, którzy nie mają zdolności reagowania lub są

\footnotetext{
12 Ibidem, s. $132-134$.

13 Jan Paweł II, Evangelium vitae, Kraków [b.d.w.], s. 120.

${ }^{14}$ R. Spaemann, T. Fuchs, Töten oder sterben lassen, Freiburg-Basel-Wien 1987, s. 34.

15 Za: R. Spaemann, G. Hohendorf, F.S. Oduncu, Vom guten Sterben, s. 28.

${ }^{16}$ R. Spaemann, Sterbehilfe ist nur ein anderes Wort für Töten, „Stuttgarter Zeitung” 26.10. 2005,
} S. 5 . 
pozbawieni świadomości. U tych osób pragnienie bycia uśmierconym jest wyłącznie zakładane i przypuszczane. Innym przypadkiem jest uśmiercanie nowonarodzonych dzieci z wysokim stopniem niepełnosprawności. W takich przypadkach używa się pojęcia eutanazji niedobrowolnej. Obie formy eutanazji, w tym uśmiercania ludzi bez jasno wyrażonego pragnienia śmierci, są praktykowane na przykład w Holandii i w Belgii, mimo że nie są zgodne z prawem o eutanazji17.

Wbrew pozorom, według słusznego stwierdzenia Spaemanna, bierną eutanazja nie jest sama rezygnacja ze stosowania środków podtrzymujących życie, takich jak na przykład sztuczne oddychanie, dializa lub leczenie zapalenia płuc z użyciem antybiotyków. Decyzja o zaniechaniu terapii może okazać się właściwa, czyli wcale nie świadczyć o umyślnym pozbawieniu życia, jeśli oznacza odstąpienie od uporczywej terapii ${ }^{18}$.

Eutanazja bierna to, według Spaemanna, zabójstwo człowieka wskutek nieuzasadnionego zaprzestania leczenia, ażeby jak najszybciej spowodować jego śmierć ${ }^{19}$. Gdyby bowiem takie leczenie było kontynuowane, organizm ludzki, mimo ciężkiej choroby, tak dalece mógłby się zregenerować, że w dalszej perspektywie byłby zdolny do życia nawet bez trwałej pomocy medycznej. Tymczasem w momencie, gdy przejściowo musiał z niej korzystać, w wyniku jej zaniechania został skazany na śmierć. Kwestia eutanazji biernej łączy się zatem ściśle z dramatyczną sytuacją pacjenta, któremu udziela się nieodzownej pomocy lekarskiej lub jej odmawia.

Życie człowieka umierającego nie musi być bowiem przedłużane za wszelką cenę przy użyciu środków medycznych i sztucznego odżywiania — podkreśla niemiecki myśliciel. Takie podejście do zagrożonego życia wskazywałoby na pewną analogię z eutanazją. Podobieństwo polega na tym, że zarówno w jednym, jak i w drugim przypadku egzystencję ludzką usiłuje się aż do ostatniej chwili reżyserować. Sądzi się bowiem, że i życie, i śmierć powinny być wytwarzane, a nie przyjmowane jako dar Boga lub losuev.

Ludzie dotknięci cierpieniem może dlatego pragną śmierci w określonym przez siebie i według ich własnego przeświadczenia właściwym czasie, ponieważ lękają się, że w trakcie swojej choroby czy dotkliwego cierpienia będą zdani na środki podtrzymujące życie, na które nie będą mieć wpływu. Zrodzi to w nich przeŚwiadczenie, że jest to życie pozbawione godności. Z punktu widzenia lekarzy ta kontrowersyjna wizja odgrywa pewną rolę. Chcą oni bowiem nie tylko sztucznie przedłużać życie, lecz także kontrolować i panować nad samą śmiercią — kontynuuje Spaemann ${ }^{21}$.

17 R. Spaemann, G. Hohendorf, F.S. Oduncu, Vom guten Sterben, s. 28.

18 Ibidem, s. 28-29. Uporczywa (nieuzasadniona) terapia to forma nieefektywnej interwencji leczniczej. Nie służy już dobru chorego, a nawet staje się dla niego zbyt uciążliwa, gdy stosuje się ją w przypadkach daleko posuniętej degeneracji organizmu i nieuchronności śmierci (A. Muszala, Encyklopedia Bioetyki, Radom 2009, s. 651).

19 R. Spaemann, Die Euthanasie debatte, Sterbehilfe ist nur ein anderes Wort für Töten, „Die Zeit” 1992, nr 12, s. 35.

${ }^{20}$ R. Spaemann, Das Gezeugte, das Gemachte und das Geschaffene, ,Scheidewege Jahrgang" 36 (2006-2007), s. 304.

${ }^{21}$ R. Spaemann, G. Hohendorf, F.S. Oduncu, Vom guten Sterben, s. 32-33. 
Jednak człowiekowi choremu, który nie jest osobą umierająca, ale całkowicie zdaną na lekarskie wsparcie nie wolno go odmawiać, pozwalajacc na przedwczesne odejście z tego świata. Sytuacja taka, powtórzmy to jeszcze raz za wybitnym myślicielem, ma miejsce wtedy, gdy według lekarskiego uznania cierpiący na poważną dolegliwość nadal przejawia zdolność przezwyciężenia kryzysu, w jakim pogrążyła go ciężka choroba. W tej dramatycznej sytuacji zaniechano jednak udzielenia mu pomocy, czyli dopuszczono się eutanazji biernej.

Czy oświadczenie pacjenta dotyczące sytuacji w przyszłości, gdy nie będzie już zdolny wyrazić swej woli (Patientenverfügung), oznacza nie wprost uznanie prawa do biernej eutanazji? W takim wypadku stanowiłoby ono dla lekarza i prawnego opiekuna zobowiązującą orientację, gdyż można w nim określić, stosownie do wprowadzonego w 2009 roku w Niemczech prawa, jak chce się być traktowanym medycznie, gdy utraciło się możliwość wyartykułowania i potwierdzenia swojej ostatniej woli. Trzeba wyraźnie podkreślić, że nie sam tego rodzaju dokument stwarza takie zagrożenie, lecz wyrażona w nim treść. Dokument ten to sensowna propozycja. Umożliwia on na przykład wyrażenie takiej oto prośby: jeżeli w wyniku wypadku nie będzie widoków mojej dalszej naturalnej egzystencji, a intensywna terapia medyczna okaże się tylko sztucznym jej przedłużeniem ${ }^{22}$, wówczas nie chciałbym być poddany takiemu leczeniu. W tym wypadku absolutnie nie można mówić o biernej eutanazji (a przynajmniej o takiej intencji), lecz tylko o słusznej rezygnacji z uporczywej terapii. W dokumencie tym jednak wolno również zaproponować przeciwnego typu rozwiązanie swojego losu w następstwie nieszczęśliwego zdarzenia, w wyniku którego, załóżmy, został trwale uszkodzony mózg. Przekreśliło to możliwość egzystencji samodzielnej i w pełni świadomej. Nie można już było nie tylko samemu decydować o sobie, lecz trzeba było zgodzić się na przykucie do łóżka i na pomoc obcych ludzi, począwszy od opiekuna prawnego. To skłoniło do podjęcia następującej decyzji: nie życzę sobie dalszego lekarskiego leczenia. Byłoby to jednak żądanie biernej eutanazji, ponieważ terapia medyczna odwróciłaby przynajmniej do pewnego stopnia tę sytuację. Pacjent dalej mógłby żyć, jakkolwiek jakość jego egzystencji nie byłaby taka sama jak wcześniej, gdyż połączona z określonymi brakami różnej natury i innymi przykrymi niedomaganiami.

\section{Czy prawo do eutanazji rodzi poczucie jej obowiązku}

Według zwolenników tak zwanej etyki łodzi ratunkowej (między innymi Johna Hardwiga ${ }^{23}$ ) prawo do śmierci w określonych sytuacjach, przede wszystkim wówczas, gdy chory staje się ciężarem nie tylko dla siebie, lecz także dla rodziny i bliskich, przeistacza się w obowiązek odejścia z tego świata ${ }^{24}$. Stanowisko to potwierdza Spaemann. Jego zdaniem ten, kto może żądać własnego uśmiercenia, ma poczucie, że staje się winien wszelkich trudów i kosztów związanych z tym, że nie

${ }^{22}$ Nie wystarczy jednak stwierdzenie, że u pacjenta wystąpiła nieodwracalnie śmiertelna choroba. Zawsze trzeba uwzględnić konkretny przypadek i konkretną chorobę.

23 John Hardwig jest profesorem bioetyki na stanowym uniwersytecie East Tennessee w USA.

${ }^{24}$ W. Bołoz, Bioetyka i prawa człowieka, Warszawa 2007, s. 216-217. 
domaga się, by go zabito. To nie los, obyczaj i oczywista solidarność żądają od najbliższych osób opieki i poświęcenia, lecz ona sama. To ona konsumuje ich majątek rodzinny, nakłada na nich obowiązki, dlatego że jest egoistą i tchórzem, który nie chce się usunąć na bok. Czy w takich okolicznościach każdy wrażliwy człowiek nie uważałby, że należy pójść za niemym gestem mówiącym: „Tu jest wyjście”? Paradoksalnie taki krok potraktowałby jako swój niemal moralny obowiązek. A zatem prawna możliwość zabijania na żądanie rzeczywiście je wywołuje - konkluduje Spaemann ${ }^{25}$. W tym wypadku dochodzi do głosu przemożna logika, zgodnie z którą prawo do eutanazji rodzi jej obowiązek i w obowiązek się zamienia. Kogoś, kto takiego obowiązku zdecydowanie nie chciałby podjąć, otoczenie wcześniej czy później potraktuje bezceremonialnie.

W Stanach Zjednoczonych zezwolenie na uśmiercanie dzieci upośledzonych przed ich urodzeniem doprowadziło już do tego, że nie udziela się kobiecie zasiłku dla dziecka niepełnosprawnego. W ten sposób, jak podkreśla Spaemann, usiłuje się wymusić na niej, by opowiedziała się przeciw życiu. W rezultacie prawo do aborcji staje się jej obowiązkiem.

Podobnie dzieje się z eutanazją ${ }^{26}$. Jeśli raz zezwoliło się uśmiercać na życzenie, nietrudno przewidzieć, jakie będą tego skutki. Otoczenie będzie wręcz oczekiwać od ludzi starych i chorych jego wyartykułowania. I w końcu rzeczywiście wyrażają oni życzenie poddania się eutanazji. Wszak we własnym odczuciu nie mają wybo$\mathrm{ru}$, nie mogą postąpić inaczej ${ }^{27}$.

Dlatego w opinii Spaemanna nie istnieje prawo do eutanazji na życzenie i tym samym uprawnienie do korzystania z pomocy w zabijaniu siebie. W każdym razie z miłości czyni się wszystko dla osoby kochanej i nie wyobraża sobie, że kiedyś przestanie ona być na tym świecie. Czyż zatem uśmiercanie tego, kto potrzebuje pomocy, nie jest przeciwieństwem logiki głębokich uczuć?28

\section{Dyskusja Roberta Spaemanna z Peterem Singerem}

W kwestii eutanazji Spaemann odnosi się krytycznie do Singera z trzech zasadniczych powodów. Pierwszy bezpośrednio łączy się z punktem wyjścia znanego australijskiego etyka w jego argumentacji za tak zwaną dobrą śmiercią. Jest nim wzgląd na status osoby. Uzasadnia to, dlaczego mówi on o dopuszczalności eutanazji w dwóch wypadkach. Może ona objąć kategorię ludzi, którzy jego zdaniem są pozbawieni godności osobowej i dlatego nie zasługują na to, żeby respektować ich prawo do życia. Jeśli są tylko poważne powody, można ich bez ponoszenia za to kary pozbawić życia. Singer ma tu na myśli embriony ludzkie, dzieci przed ukończeniem pierwszego miesiąca życia ${ }^{29}$, ciężko upośledzonych umysłowo i dotkniętych tak zwaną demencją

\footnotetext{
${ }^{25}$ R. Spaemann, Nie istnieje dobre zabijanie, s. 515.

${ }^{26}$ R. Spaemann, Töten auf Verlangen?, s. 48.

27 R. Spaemann, Sind alle Menschen Personen?, s. 426.

${ }^{28}$ R. Spaemann, Töten auf Verlangen?, s. 46; R. Spaemann, Osoby, O różnicy między czymś a kimś, tłum. J. Merecki, Warszawa 2001, s. 197.

${ }^{29}$ P. Singer, Etyka praktyczna, tłum. A. Sagan, Warszawa 2003, s. 167-168.
} 
starczą. Istotom tym brakuje tego, co w jego opinii definiuje rzeczywistość osoby, to jest samoświadomości i racjonalności. Zasadność takiej argumentacji Spaemann jednoznacznie podważa przez przywołanie klasycznego rozumienia osoby (uznawanego tak przez św. Tomasza z Akwinu, jak i przez Kanta), zgodnie z którym każdy człowiek od pierwszej chwili swego zaistnienia jest obdarzony godnością osobową. O jej tożsamości nie rozstrzygają bowiem określone właściwości i umiejętności. Stanowi o niej to, że jest ich podmiotem jako nasze ,,ja”, odkrywane w bezpośrednim wewnętrznym doświadczeniu. Każdy z nas jest kimś, a nie czymś jako istota o naturze racjonalnej, potencjalnie zdolnej do aktów rozumnych i do tego, by znajdować się w stanach specyficznych dla osoby, nawet jeśli w określonej fazie egzystencji czy $\mathrm{w}$ danej chwili okazuje się to niemożliwe. Z tego tytułu od pierwszego momentu swego zaistnienia mamy własne prawa, łącznie z najbardziej fundamentalnym prawem do życia. Jednocześnie, jak podkreśla Spaemann, Singer zasługuje na szacunek dlatego, że w jednym, acz znamiennym wypadku zamanifestował postawę, która zaprzeczała temu, co zawarł w swej teorii o eutanazji i ludziach, których nie uważał za osoby (chorzy psychicznie). Z podziwu godnym poświęceniem zaopiekował się swą matką chorą na alzheimera. Tego rodzaju niekonsekwencję usprawiedliwił stwierdzeniem: „To jest moja matka"30.

Uzasadnienie dla aktów eutanazyjnych Singer znajduje następnie w samym statusie osoby jako istoty zdolnej do samostanowienia (wolności) i autonomii. Fakt ten, jego zdaniem, uprawnia nas do tego, kiedy i w jaki sposób chcemy skończyć swoje życie ${ }^{31}$. Spaemann znowu kategorycznie neguje tego rodzaju argumentację, podkreślając, że nie na tym polega właściwe korzystanie z tego uzdolnienia, by służyło ono do samodestrukcji bytu osobowego. Zgadza się z Kantem, według którego człowiek, który na mocy własnego wyboru unicestwia swą osobę, działa wbrew swej godności, redukując siebie do funkcji narzędzia ${ }^{32}$. Ponadto Spaemann akcentuje, że w rzeczywistości żądanie eutanazji najczęściej nie jest czysto autonomicznym aktem pacjenta ${ }^{33}$.

Spaemann całkiem inaczej aniżeli Singer rozumie również argument równi pochyłej, który powinien przemawiać przeciwko legalizacji eutanazji. Argument tego typu ma charakter empiryczny, ale nie jest też bez znaczenia filozoficznie. Pozwala on zauważyć, jak zmienia się moralne nastawienie w wyniku tego, że zaczęto czynić to, czego czynić nie wolno. Jeśli więc zrobiło się pierwszy krok, który jest moralnie zły, to choćby był on mały, to jednak otwiera drzwi do następnego kroku o podobnym charakterze. Prawdę o tym tradycja ludowa zawarła w przysłowiu: „Niszcz zło w zarodku i przeszkadzaj początkom” („Wehret den Anfängen”). Należy zatem rzeczywiście starannie rozważyć ten pierwszy krok.

Tymczasem, według Singera, nie ma dowodów, które potwierdziłyby słuszność tego rodzaju argumentacji i tym samym mogły przestrzec przed prawnym uznaniem eutanazji oraz traktowaniem jej jako moralnie usprawiedliwioną. Jak podkre-

${ }^{30}$ R. Spaemann, Es ist kein gutes Töten, [w:] R. Spaemann, G. Hohendorf, F.S. Oduncu, Vom guten Sterben, s. 153.

${ }^{31}$ H. Kuhse, Eutanazja, [w:] Przewodnik po etyce, P. Singer (red.), Warszawa 2002, s. 345.

32 R. Spaemann, Śmierć — samobójstwo - eutanazja, ,Ethos” 12 [347] (1999), s. 118.

33 R. Spaemann, Nie istnieje dobre zabijanie, s. 521. 
śla, tam gdzie to nastąpiło, nie pchnęło tego społeczeństwa po równi pochyłej ${ }^{34}$. Ma on na myśli „kraj tulipanów”, w którym odważono się na „społeczny eksperyment" aktywnej, dobrowolnej eutanazji. Fakty jednak przeczą trafności tezy i zapatrywania etyka o orientacji utylitarystycznej. Zabijanie na życzenie okazało się rodzajem miękkiego narkotyku, który był pierwszym krokiem do zniesienia tabu zabijania ,życia niewartego życia” również bez zgody zainteresowanego ${ }^{35}$.

Widzimy to właśnie na przykładzie Holandii, a także Belgii, gdzie najpierw zezwolono na eutanazję dobrowolną. Nie brakowało tam głosów usiłujących przestrzec przed fatalnymi konsekwencjami takiej decyzji. Niestety aktualnie dokonuje się w tych krajach również eutanazji niedobrowolnej, której w Holandii pada ofiarą jedna trzecia spośród całej liczby osób umierających wskutek eutanazji ${ }^{36}$. Ponadto w tych krajach świadomość, że eutanazja to akt moralnie naganny coraz bardziej się zaciera.

Wreszcie Spaemann zarzuca Singerowi, że nie odróżnia on dwóch rodzajów zaniechania $\mathrm{w}$ dramatycznej walce o utrzymanie przy życiu pacjenta czy też przedłużenie jego egzystencji. Jedno z nich bywa często uzasadnione, a wtedy nie można go określić jako eutanazję bierną. Tymczasem, jak podkreśla niemiecki myśliciel, Singer sugeruje, że pozwolenie na śmierć $z$ powodu odwodnienia ${ }^{37}$ i rezygnacja $z$ aparatu oddechowego są takim samym rodzajem zaniechania działania, gdyż w obydwu przypadkach prowadzi to do śmierci ${ }^{38}$. Jednak tylko pierwsze z nich oznacza dopuszczenie się eutanazji biernej, jako że raczej nigdy nie wolno zaprzestać nawadniania chorego $^{39}$. Natomiast drugie niejednokrotnie jest uzasadnione ${ }^{40}$, a nawet nieuniknione i dlatego nie ma nic wspólnego z zabójstwem drugiej osoby.

${ }^{34}$ Ibidem, s. 345. Należy przypuszczać, że jest to jednocześnie stanowisko P. Singera, ponieważ zostało wyrażone w cytowanej powyżej książce Przewodnik po etyce, której jest redaktorem.

${ }^{35}$ R. Spaemann, Nie istnieje dobre zabijanie, s. 516-517.

36 Ibidem, s. 517. Por. także R. Spaemann, G. Hohendorf, F.S. Oduncu, Vom guten Sterben, s. 132.

37 Odwodnienie związane jest z niepodawaniem napojów, a to powinno się czynić na ogół zawsze i do końca życia chorego. Nawadniać można przecież również pozajelitowo. Dlatego nigdy nie wolno zaniechać tej formy pomocy medycznej.

${ }^{38}$ R. Spaemann, Nie istnieje dobre zabijanie, s. 511.

39 Według Kongregacji Nauki Wiary (Odpowiedzi na pytania dotyczące sztucznego odżywiania i nawadniania) istnieje moralny obowiązek podawania pokarmu i wody (w sposób naturalny i sztuczny) pacjentowi „w stanie wegetatywnym”, z wyjątkiem przypadków, gdy takie pożywienie nie może być podawane bez powodowania znacznej dolegliwości fizycznej. Za: E. Kowalski, Osoba i Bioetyka, Kraków 2009, s. 322.

40 Jeżeli chory znajduje się już w stanie agonii (stan bezpośrednio przedśmiertny) lub dotknięty jest chorobą śmiertelną, która wkracza w ostatnie swoje stadium i nie odzyska własnego oddechu, wówczas może zrezygnować ze środków nadzwyczajnych (na przykład respiratora lub chemioterapii). Jest to rezygnacja z uporczywości terapeutycznej, która dostarcza jeszcze więcej cierpień (z powodu syndromu zamknięcia pacjenci są bezwolni, a jedynie maszyna za nich oddycha). Stwierdzenie, że nie ma moralnego obowiązku podtrzymywania życia osoby ludzkiej za wszelką cenę w kontekście etyki chrześcijańskiej nie będzie nigdy oznaczało osądu dotyczącego rzekomo niskiej jakości, a więc także małej wartości życia umierających, a będzie raczej wyrazem pogodzenia się z ludzką kondycją i akceptacji nieuchronności śmierci. M. Machinek, Uporczywość terapeutyczna jako problem teologiczno-moralny, „Communio” 32, 2012, nr 3, s. 93. 


\section{Specyfika filozoficznych podstaw argumentacji Spaemanna}

Specyfika filozoficznych podstaw argumentacji Spaemanna wiąże się między innymi z charakterem oceny eutanazji. Formułuje on ją w kontekście idei godności osobowej człowieka, którą rozumiał klasycznie w duchu Boecjusza, św. Tomasza z Akwinu i Kanta. Dlatego według niego osoba to inaczej każdy człowiek od pierwszej chwili swego zaistnienia aż do ostatniego momentu naturalnej egzystencji. Eutanazja we wszelkiej swej postaci jawi się jako czyn przeciwny naszej osobowej godności, której minimum posiada każdy z nas z racji bycia człowiekiem. Akt ten oznacza bowiem potraktowanie osoby w sposób zupełnie przeciwny temu, jakiego domaga się jej szczególny status. Niektórych czynności nie da się pogodzić z godnością, a wśród nich zwłaszcza zabójstwa - akcentuje wybitny myśliciel ${ }^{41}$. Tymczasem eutanazja jest właśnie niczym innym jak tylko świadomie i bezpośrednio dokonanym uśmierceniem osoby.

W czym jednak ujawnia się specyfika ujęcia Spaemanna w porównaniu do stanowiska reprezentowanego przez zwolenników legalizacji eutanazji z kręgu nurtu utylitarystycznego, takich jak Peter Singer, Derek Parfit, Norbert Hoerster. Oni również dowodzą słuszności swego stanowiska przez odwołanie się do idei godności osobowej. Na temat eutanazji wygłaszają jednak tezy zgoła nieprzystające do tej idei. Recz w tym, że są to reprezentanci i duchowi synowie Lockowskiej teorii osoby, wedle której nie wszystkich ludzi należy uważać za osoby. Takich naszych bliźnich, którzy — ich zdaniem — nie są jeszcze bytami tej rangi lub przestali nimi być, wolno pozbawić życia. Jednocześnie według wymienionych przedstawicieli utylitaryzmu godność osobowa daje prawo do tak zwanej dobrej śmierci. Człowiek bowiem za sprawą swej zdolności samostanowienia, czyli ostatecznie swej godności (godność to rozumność i możliwość samostanowienia ${ }^{42}$ ), ma do tego prawo.

Sens samostanowienia (wolności) nie może jednak polegać na tym, żeby stawiać je ponad tym, co je umożliwia, czyli ponad życiem — zauważa słusznie Spaemann ${ }^{43}$. Byłby to akt niedorzeczny. Niestety usprawiedliwianie eutanazji świadczy, że tak tę kwestię się rozwiązuje, ponieważ w jej wyniku sam podmiot samostanowienia przestaje istnieć. Naturalnie zwolennicy tak zwanej dobrej śmierci mogą taki zarzut odeprzeć stwierdzeniem: w tym przejawia się absolutna wolność, że nawet samego siebie można unicestwić. Taka argumentacja brzmi jednak nader cynicznie.

\section{Bibliografia}

Bołoz W., Bioetyka i prawa człowieka, Warszawa 2007.

Habermas J., Przyszłość natury ludzkiej Czy zmierzamy do eugeniki liberalnej, tłum.

M. Łukasiewicz, Warszawa 2003.

${ }^{41}$ R. Spaemann, O pojęciu godności człowieka, [w:] idem, Granice. O etycznym wymiarze działania, s. 163 .

42 Ibidem, s. 158.

${ }^{43}$ R. Spaemann, Nie istnieje dobre zabijanie, s. 518. 
Hermann A., Euthanasie, [w:] Historisches Wörterbuch der Philosophie, J. Ritter (red.), t. 2, Basel-Stuttgart 1972, s. 828-829.

Kowalski J., Osoba i Bioetyka, Kraków 2009.

Kożuchowski J., O człowieku i moralności w filozofii Roberta Spaemanna, Lublin 2013.

Kuhse H., Eutanazja, [w:] Przewodnik po etyce, P. Singer (red.), Warszawa 2002, s. $337-347$.

Machinek M., Uporczywość terapeutyczna jako problem teologiczno-moralny, „Communio" 3 [32] (2012), s. 88-102.

Muszala A., Encyklopedia Bioetyki, Radom 2009.

Singer P., Etyka praktyczna, tłum. A. Sagan, Warszawa 2003.

Spaemann R., Die Euthanasiedebatte, Sterbehilfe ist nur ein anderes Wort für Töten, „Die Zeit” 12 (1992), s. 14-15.

Spaemann R., Das Gezeugte, das Gemachte und das Geschaffene, „Scheidewege Jahrgang" 36 (2006-2007), s. 301-310.

Spaemann R., Die Herausforderung der Zivilisation, [w:] Was den Menschen macht, O. Talmain, W. Schweidler (Hrsg.), Bd. 16, Münster-Hanover-London 2003, s. 11-20.

Spaemann R., Es ist kein gutes Töten, [w:] Vom guten Sterben, R. Spaemann, G. Hohendorf, F.S. Oduncu, Freiburg-Basel-Wien 2015, s. 130-152.

Spaemann R., Glück und Wohlwollen Versuch über Ethik, Stuttgart 1993.

Spaemann R., Nie istnieje dobre zabijanie, [w:] idem, Granice o etycznym wymiarze działania, tłum. J. Merecki, Warszawa 2006, s. 509-526.

Spaemann R., Osoby. O różnicy między czymś a kimś, tłum. J. Merecki, Warszawa 2001.

Spaemann R., Sterbehilfe ist nur ein anderes Wort für Töten, „Stuttgarter Zeitung”, 26.10. 2005, s. 10-12.

Spaemann R., Śmierć - samobójstwo - eutanazja, „Ethos” 12 [347] (1999), s. 107-115.

Spaemann R., Töten auf Verlangen?, „Psychologie heute” 25 [2] (1999), s. 44-49.

Spaemann R., Fuchs T., Töten oder sterben lassen, Freiburg-Basel-Wien 1987.

Spaemann R., Hohendorf G., Oduncu F.S., Vom guten Sterben, Freiburg-Basel-Wien 2015.

Spaemann R., Wprowadzenie, [w:] Globalna rewolucja seksualna, G. Kuby (red.), Kraków 2012, s. 17-19.

Wald B., Menschenwürde und Menschenrechte, [w:] Naturrecht und Kirche in säkularen Staat, H.C. Niesing (hrsg.), Wiesbaden 2016, s. 53-74. 